\title{
Natural Products from Plant-associated Microorganisms: Distribution, Structural Diversity, Bioactivity, and Implications of Their Occurrence ${ }^{\perp}$
}

\author{
A. A. Leslie Gunatilaka* \\ Southwest Center for Natural Products Research and Commercialization, Office of Arid Lands \\ Studies, College of Agriculture and Life Sciences, University of Arizona, 250 E. Valencia Road, \\ Tucson, Arizona 85706-6800
}

\begin{abstract}
A growing body of evidence suggests that plant-associated microorganisms, especially endophytic and rhizosphere bacteria and fungi, represent a huge and largely untapped resource of natural products with chemical structures that have been optimized by evolution for biological and ecological relevance. A diverse array of bioactive small molecule natural products has been encountered in these microorganisms. The structures of over 230 metabolites isolated and characterized from over 70 plant-associated microbial strains during the past four years are presented with information on their hosts, culture conditions, and biological activities. Some significant biological and ecological implications of their occurrence are also reviewed.
\end{abstract}

\section{Introduction}

\begin{abstract}
Among all known producers of small molecule natural products, microorganisms represent a rich source of biologically active metabolites that find wide-ranging applications as agrochemicals, antibiotics, immunosuppressants, antiparasitics, and anticancer agents. Unlike other organisms, microbes occupy all living and non-living niches on earth including arctic, antarctic and alpine regions, deserts, deep rock sediments, marine environments, and even thermal vents. Microorganisms, commonly isolated from soil, can also be found in live plants, leaf litter, and dung. ${ }^{1}$ It has been estimated that less than $1 \%$ of bacterial species and less than 5\% of fungal species are currently known, suggesting that millions of microbial species remain to be discovered. ${ }^{2}$ There is evidence that the currently available culture techniques are capable of uncovering only a miniscule fraction of soil microbes. ${ }^{3}$ Thus, recent developments of techniques for cultivating and identifying microorganisms involving application of parallel cultivation of gel-encapsulated single cells, ${ }^{4}$ and the approach involving isolation of DNA directly from soil (environmental DNA, eDNA), making cosmid libraries of eDNA in E. coli, and screening these libraries for clones with the ability to biosynthesize bioactive natural products, ${ }^{5}$ and the incorporation of host plant extracts to culture media ${ }^{6}$ are significant advances towards characterizing metabolites produced by "difficult-to-culture" and "unculturable" soil and plant-associated microorganisms. Another significant recent development in the field of microbial natural products is the demonstration of the potential to bring up a variety of new metabolites from a single strain of a
\end{abstract}

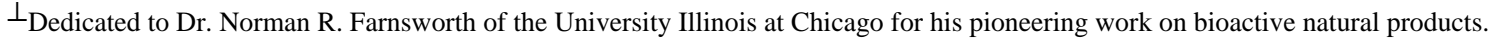
*Author to whom correspondence should be addressed. Tel: (520) 741-1691. Fax: (520) 741-1468. leslieg @ ag.arizona.edu.. Supporting Information Available: Figure showing biogenetic relationship of compounds 100 and $\mathbf{1 0 3}$ - 105. This information is available free of charge via the Internet at http://pubs.acs.org.
} 
microorganism by systematic alteration of its cultivation parameters, known as OSMAC (one strain many compounds) approach. ${ }^{7}$

Historically, of all microorganisms studied, Actinomycetes and fungi have been found to be the most prolific producers of secondary metabolites. It has been suggested that fungi are fundamental to the health and prosperity of every terrestrial ecosystem and are essential for their sustainability and biodiversity. ${ }^{8 \mathrm{a}, \mathrm{b}}$ Evolutionary biologists have long appreciated that fungal life cycles are intricately and ubiquitously linked with those of plants. There is ample circumstantial evidence to suggest that symbiosis of fungi and plants assisted in the original invasion of plants into early harsh terrestrial environments that were poor in nutrients, subject to constant desiccation, and poorly shaded exposing these habitats to the bright light of the day. ${ }^{9 a}$ Although recent advances in fungal systematics have outdated some of the evolutionary speculations that led to the above proposition, the basic premise that symbiotic relationships between arbuscular mycorrhizal (AM) fungi and the roots of higher plants were essential in the migration of plants to land continues to be widely accepted. ${ }^{9 b}$

Microorganisms have the ability to utilize various solid substrates as a consequence of diversity of their biological and biochemical evolution; the solid substrates utilized by microorganisms include, among others, live plants. Both bacteria and fungi are known to collaborate with many plants to form mutually beneficial (mutualistic) associations. The purpose of this review is to summarize the distribution, chemistry and biological functions of natural products of microorganisms that live in close association with terrestrial and mangrove plants. These include endophytic and rhizosphere microorganisms. This review covers the literature available in Chemical Abstracts up to November 2005 and contains brief discussions of distribution, structural diversity, biological activities, significance and implications of the occurrence of natural products of plant-associated microorganisms.

\section{Endophytic Microorganisms}

The term endophyte refers to a bacterial or a fungal microorganism that colonizes interior organs of plants, but does not have pathogenic effects on its host(s). In their symbiotic association, the host plant (macrophyte) protects and feeds the endophyte, which "in return" produces bioactive metabolites to enhance the growth and competitiveness of the host and to protect it from herbivores and plant pathogens. ${ }^{10}$ Among endophytic microorganisms endophytic fungi, consisting mostly of Ascomycetes and Fungi Imperfecti, represent one of the largest - conservatively $1.5 \times 10^{6}$ species - and relatively untapped resource of biologically active small molecule natural products. ${ }^{11}$ Although the first discovery of an endophyte was made as far back as $1904,{ }^{2}$ this group of microorganisms did not receive much attention until the recent realization of their ecological relevance and the potential of yielding metabolites with diverse structures and biological functions. Thus, during the past two decades over 100 endophytic microorganisms have been cultured and subjected to detailed investigations leading to the chemical characterization and biological evaluation of a large number of natural products, many of which have been shown to have novel structures and interesting biological activities.

Current interest in natural products from endophytic microorganisms is evident from the number of review articles that have appeared in the recent literature. The first of these by Gusman and Vanhaelen ${ }^{13}$ described secondary metabolites of 38 endophytic fungi together with their biological activities. In a more comprehensive review, Tan and Zou ${ }^{14}$ have presented 138 secondary metabolites of endophytes characterized before the year 2000. The reviews by Schulz et al., ${ }^{15}$ Strobel, ${ }^{16,17}$ and Strobel et al. ${ }^{18 \mathrm{a}}$ deal primarily with the work on endophytes carried out in their own laboratories. More specialized reviews have also appeared on bioactive compounds of endophytes, ${ }^{19}$ and of four endophytic Penicillium sp. 
of a US Northwest Pacific yew tree. ${ }^{20}$ Since the appearance of the last comprehensive review by Tan and Zou, ${ }^{14} 184$ metabolites, of which 96 are new, have been characterized from 59 strains of endophytic microorganisms. The time is thus ripe for a comprehensive review of natural products from these fascinating organisms. Presented in Table 1 are endophytic microbial strains, host plants from which these microbes have been isolated, culture conditions employed for isolation of secondary metabolites, natural products characterized together with their reported biological activities, if any, and the literature references. ${ }^{7,21-74}$ Conditions employed for culturing of microorganisms are included in Table 1 as it is known that the nature and yield of microbial metabolites are strongly influenced by cultivation parameters. ${ }^{7}$

\section{Rhizosphere Microorganisms}

The rhizosphere is a biologically active zone of the soil around roots of plants that contain soil-borne microbes including bacteria and fungi. ${ }^{75}$ It is the region of the soil immediately adjacent (within $1 \mathrm{~mm}$ ) to plant roots and supports microbial ecosystems that are different from those of the bulk soil, both in gross numbers of cells, and the variety of strains represented. ${ }^{76}$ This special niche is heavily influenced by plant root rhizo-deposition products that are composed of exudates, lysates, mucilage, secretions and dead cell material, as well as gases including respiratory $\mathrm{CO}_{2} \cdot{ }^{77}$ The amount and contents of these materials is also highly variable depending on the plant species, developmental stage of the plant, soil type, environmental stress, plant nutrition and other factors affecting plant growth, and the microbial activity in the rhizosphere. ${ }^{78}$ The rhizosphere is also an environment with complex ecological interactions among the members of the microbial community, including competition via "chemical warfare." 79 The microbial communities present in the rhizosphere also influence growth and even survival of the plant host depending on the degree of parasitism, pathogenicity, or conversely, via induced disease resistance or biocontrol of pathogens. ${ }^{79 a, 80}$ As a consequence, the diversity of microbial strains in the rhizosphere has been postulated to be influenced by different plant species, ${ }^{81}$ their phylogeny, and environmental factors affecting plant growth. ${ }^{82}$ Recent results have substantiated these hypotheses; techniques based on the analysis of microbial DNA extracted from rhizosphere communities (such as $16 s$ RNA sequence analysis and DNA melting hybridization) as well as analysis of fatty acid metabolic profiles indicate that the rhizosphere communities of plant species differ from each other and from non-rhizosphere communities in the surrounding soil. ${ }^{76,83}$

The demonstration that rhizosphere microbial diversity is strongly influenced by the diversity of plant species and environmental factors suggests that a previously unexploited opportunity exists for harvesting of natural products from this group of plant-associated microorganisms. Surprisingly, the secondary metabolites of rhizosphere microorganisms have not received much attention compared with those of endophytes although a recent study has found that actinomycete producers of antifungal compounds could be isolated with higher frequency from the rhizosphere bacteria of the big sagebrush (Artemisia tridentata) than from bacterial communities of the bulk soil. ${ }^{84}$ Our pioneering work on nine strains of Sonoran desert plant-associated rhizosphere fungi has thus far resulted in the characterization of 41 metabolites of which 18 are new natural products. ${ }^{85-90}$ Presented in Table 2 are the rhizosphere microorganisms investigated, their host plants, culture conditions employed for isolation of secondary metabolites, natural products encountered, and their biological activities. 


\section{Structural Diversity and Biological Activities}

As has been recently pointed out by Bode et al., ${ }^{7 \text { a }}$ "with more than 20,000 compounds described in the literature, microorganisms must be called metabolic artists superior to any metabolic diversity created by man." In addition, microbial natural products represent a huge and largely untapped resource of unique chemical structures that have been optimized by evolution and are produced for communication and in response to changes in their habitats including environmental stress. Thus, there exists the potential of harvesting novel and/or biologically relevant natural products from organisms that live in close association with each other such as plant-associated microorganisms. This is evident from characterization of over 400 natural products to date, of which most have novel structures and/or useful biological activities, from 128 plant-associated microorganisms. The following discussion will focus mainly on natural products from endophytic and rhizosphere microorganisms with novel structures and/or interesting biological activities.

\section{Metabolites of Acetate (Polyketide) Origin}

Natural products frequently encountered in plant-associated microorganisms include, as in microorganisms from other sources, those derived from the acetate (polyketide) pathway. Of about 230 natural products characterized from these microorganisms during the period covered in this review, nearly half (115) are acetate-derived $(\mathbf{1}-\mathbf{5 2})$. The new glycosphingolipid cerebroside, fusaruside (4b), isolated from the endophyte Fusarium sp. IFB-121 occurring in Quercus variabilis has been shown to have antibacterial and xanthine oxidase inhibitory activities. ${ }^{38}$ Phomol (5) is a novel polyketide lactone with antibacterial, antifungal, and anti-inflammatory activities characterized from an unidentified Phomopsis sp. endophytic in the Argentinian medicinal plant, Erythrina crista-galli. ${ }^{57}$ The presence of at least six stereochemical centers in $\mathbf{5}$ has been recognized, but application of NMR techniques (e.g., NOESY) for the determination of relative stereochemistry of these centers has failed. Two new lactones, 1893 A (7) and 1893 B (8), structurally related to the soilborne fungal metabolite, mycoepoxydiene, ${ }^{69 \mathrm{~b}}$ were reported to occur in an unidentified endophytic fungus No 1893 isolated from the estuarine mangrove, Kandelia candel. ${ }^{69 a}$ Although the extract from which these were isolated was shown to be cytotoxic and strongly insecticidal, the bioactivities of $\mathbf{7}$ and $\mathbf{8}$ have not been evaluated. (-)-Oocydin A (9) is a unique chlorinated macrocyclic lactone isolated from an unusual bacterial strain of Serratia marcescens occurring both as an endophyte and an ephiphyte of the aquatic plant, Rhyncholacis penicillata. ${ }^{18 \mathrm{~b}, 61}$ The potential of oocydin A as an agrochemical to control oomyceteous fungi including Pythium and Phytopthora spp. is currently being evaluated. ${ }^{18 \mathrm{~b}}$ Characterization of the macrolide (-)-haterumalide NA structurally identical with (-)oocydin A (9) from an Okinawan sponge has been reported simultaneously. ${ }^{18 \mathrm{c}}$ More intriguingly, oocydin A/haterumalide NA (9) was also found to occur in the soil bacterium, Serratia plymuthica. ${ }^{18 \mathrm{~d}}$ The previously known macrolide fungal metabolite, brefeldin A (10) with a wide range of biological activities has been found to occur in Aspergillus clavatus and Paecilomyces sp. endophytic in Chinese Taxus mairei and Torreya grandis. ${ }^{8 \mathrm{~b}}$ Mutualism developed between these organisms has been suggested to utilize brefeldin A to protect the host plant from bacterial infection, insects and animals; it is proposed that this compound may also affect the normal function of the secretory system of plant cells by inhibiting vesicle formation at the Golgi apparatus ${ }^{8 f}$ which would enable these endophytes to obtain nutrients easily from their hosts. Fusidilactones A (11a), B (11b), and C (12) are new polycyclic lactones encountered in a Fusidium sp. endophytic in Mentha arvensis. ${ }^{39}$ The structural complexity of fusidilactone $\mathrm{C}(\mathbf{1 2})$ with a rare oxoadamantane moiety has been suggested to be similar to that of the poison tetrodotoxin produced by the Japanese fish Spheroides rubripes. 
A series of new orsellinic acid esters, globosumones A - C (17b-17d), of which 17b and 17c exhibit cytotoxicity, have been reported from Chaeotomium globosum endophytic in mormon tea (Ephedra fasciculata). ${ }^{31}$ Pestacin (21) and isopestacin (22) are two antifungal and antioxidant isobenzofuran metabolites produced by the endophytic fungus Pestalotiopsis microspora isolated, respectively, from several plants native to the rainforest of Papua New Guinea, and from Terminalia morobensis. ${ }^{55}$ Molecular mechanisms for the racemization of pestacin (21) during its biosynthesis, and its antioxidant activity have been proposed. ${ }^{55}$ Five new octaketides, cytosporones A (26a), B (26b), C (27a), D (27b), and E (28), have been reported from two endophytic fungal strains CR 200 (Cytospora sp.) and CR 146 (Diaporthe sp.) collected in Costa Rica. ${ }^{34}$ Of these, only those metabolites with a trihydroxybenzene lactone moiety (cytosporones $\mathrm{D}$ and $\mathrm{E}$ ) were found to exhibit antibacterial activity.

Cytosporone $\mathrm{B}$ (26b), three of its new analogs bearing hydroxyl groups in the $\mathrm{C}_{8}$ alkyl chain, dothiorelones A - C (26c-26e), and the lactone, dothiorelone D (27c) were found to occur in Dothiorella sp. HTF3. ${ }^{35 a}$ Cytosporone B (26b) has been recently shown to have antifungal and cytotoxic activities. ${ }^{35 \mathrm{~b}}$ Natural occurrence of dothiorelone A (26c) has led to the proposition that it may be a biosynthetic precursor of the macrocyclic fungal metabolite, curvularin (29a). ${ }^{35 a}$ a, $\beta$-Dehydrocurvularin (29b) has been encountered in the endophytic fungus, Nectria galligena ${ }^{49}$ and the rhizosphere fungal isolates, Aspergillus terreus ${ }^{85 a}$ and Penicillium sp.; ${ }^{90}$ analogs of 29a, 11-hydroxycurvularin (29c) and 11-methoxycurvularin (29d), were also found to occur in the latter two fungi. The cytotoxic and heat shock protein-90 (Hsp90) inhibitory macrocyclic lactones, monocillin I (30a) and its chlorinated analog, radicicol (30b) have been isolated from Paraphaeosphaeria quadriseptata occurring in the rhizosphere of the Christmas cactus, Opuntia leptocaulis, ${ }^{30,89 a}$ and Chaetomium chiversii endophytic on Mormon tea (Ephedra fasciculata). ${ }^{30}$ Three novel minor isocoumarins, paraphaeosphaerins A - C (33a-33c), biogenetically related to monocillin I (30a), were also found to occur in P. quadriseptata. ${ }^{89 \mathrm{~b}}$ Investigation of the rhizosphere fungal isolate, Chaetomium globosum, collected from Opuntia leptocaulis, has led to the isolation of a novel strongly cytotoxic dihydroxanthone, globosuxanthone A (38), two new xanthones, globosuxanthones B (39a), and C (39b) together with the known hydroxyvertixanthone (39c). ${ }^{39}$ Use of a biochemical induction assay (BIA), which measures the induction of the SOS response in bacteria, has led to the isolation of the bisanthrones, cytoskyrins A (41) and B (42), from Cytospora sp. CR200, a fungal strain endophytic in Conocarpus erecta. ${ }^{3 \mathrm{~b}}$ Of these, only cytoskyrin A was found to be active in the BIA. Along with three known bis-spirobisnaphthalones, preussomerins $G-I(\mathbf{4 3 a}-\mathbf{4 3 c})$, three new representatives, preussomerins J (43d), K (43e), and L (44), have been reported from Mycelia sterilia, a fungus endophytic in Atropha belladonna. ${ }^{48}$ Comparison of experimental and calculated $\mathrm{CD}$ spectroscopic data has aided determination of the absolute configurations of these preussomerins. The nontoxic plant growth inhibitory bis-coumarin, orlandin (52a), previously encountered in Aspergillus niger growing on orange leaves, ${ }^{32 \mathrm{a}}$ and its methyl ether, kotanin (52b) have been isolated from Cladosporium herbarum endophytic in Cynodon dactylon. ${ }^{32 \mathrm{~b}}$

\section{Metabolites of Mevalonate Origin}

The second most prevalent group of natural products in plant-associated microorganisms are those derived from the mevalonic acid pathway, and $29(\mathbf{5 3}-\mathbf{7 0})$ out of about 230 natural products encountered during the period of this review belong to this category. These include sesquiterpenoids, diterpenoids, triterpenoids and steroids. Two new derivatives of the sesquiterpenoid (+)-terrecyclic acid A (56a) namely, (+)-5,6-dihydro-6-hydroxyterrecyclic acid $\mathrm{A}(\mathbf{5 6} \mathbf{b})$ and (+)-5,6-dihydro-6-methoxyterrecyclic acid A (56c) together with 56a and the derived cyclic lactone, (-)-quadrone (55) have been found to be the major constituents of the Sonoran desert rhizosphere fungal isolate, Aspergillus terreus. ${ }^{87 a}$ Cytotoxicity exhibited by these compounds towards proliferating cancer cell lines has led to a limited structure- 
activity relationship (SAR) study and evaluation of the possible mechanism of cytotoxic activity of 56a as due to the modulation of multiple stress pathways - the oxidative, heat shock, and inflammatory responses - in tumor cells that promote their survival. ${ }^{87 \mathrm{~b}}$ Leptosphaeric acid (57) is a sesquiterpene with a new rearranged carbon skeleton occurring in a partially identified Leptosphaeria sp., a fungus endophytic in Artemisia annua. ${ }^{42 a}$

Guanacastepenes A - O (58a- 64b) are a series of diterpenoids encountered in an unidentified endophytic fungal strain CR115 (with $90 \%$ similarity to an uncharacterized oat root Basidiomycete) occurring in Daphnopsis americana. ${ }^{68}$ Of these, guanacastepenes A (58a) and I (61d) were found to have antibacterial activity against drug-resistant strains of Staphylococcus aureus and Enterococcus faecalis. This structurally diverse group of diterpenes has been postulated to represent five biogenetically related ring systems, some of which contain heterocyclic rings with nitrogen and oxygen atoms. ${ }^{68 \mathrm{~b}}$ Two new fusicoccane diterpenoids, periconicins A (65a) and B (65b) isolated from an endophytic fungal strain Periconia sp. inhabiting the inner bark of Taxus cuspidata, ${ }^{53 a}$ have been shown to have an array of biological properties including antimicotic (against the agents of human mycoses, Candida albicans, Trichophyton mentagrophytes, and T. rubrum), and plant growth regulatory activities (inhibition of hypocotyl elongation and root growth of Brassica campestris and Raphanus sativus). ${ }^{53 \mathrm{~b}}$ Interestingly, at concentrations below $1 \mu \mathrm{g} / \mathrm{mL}$ both compounds were found to accelerate root growth. Enfumafungin (66) is a new antifungal triterpenoid glucoside produced by Hormonema sp. (ATCC 74360), a fungus endophytic in Juniperus communis. ${ }^{41}$ The interesting antifungal spectrum exhibited by $\mathbf{6 6}$ and its effect on morphology of Aspergillus fumigatus, which was shown to be comparable to that of the glucan synthase inhibitor, pneumocandin $\mathrm{B}_{0}$ [the natural precursor of the clinical candidate MK-0991 (caspofungin acetate)], has led to an extensive search for other Hormonema isolates from different geographic locations and hosts for enfumafungin (66). Of the 53 isolates screened, antifungal activity was detected in five strains, but by HPLC analysis only two of them were found to produce 66, in amounts similar to the strain ATCC $74360 .{ }^{41}$

\section{Metabolites of Shikimate Origin}

Microorganisms and plants often utilize shikimate pathway as a route alternative to the acetate (polyketide) pathway for the production aromatic compounds. In microorganisms, metabolites of shikimate origin include, among others, aromatic amino acids and their $N$ containing derivatives, phenylpropanoids, benzoic acid, and $p$-aminobenzoic acid derivatives. ${ }^{91}$ Three new $p$-aminoacetophenonic acids, 71a - 71c, have been reported recently from the endophytic bacterial isolate, Streptomyces griseus obtained from the mangrove plant Kandelia candel. ${ }^{64}$ Although these appear to be biogenetic precursors of aminoacetophenone heptaene antibiotics, such as levorin and trichomycin produced by Streptomyces, none of the new $p$-aminoacetophenonic acids, 71a-71c, displayed any antibacterial, antifungal, or cytotoxic activity.

\section{Metabolites of Mixed Biosynthetic Origin}

A number of metabolites of plant-associated microorganisms incorporate within their structures the biosynthetic sub-units of two (rarely more) metabolic pathways. It is noteworthy that out of over 230 natural products encountered during the period covered in this review, $27(\mathbf{7 2}-\mathbf{8 7})$ are of mixed biosynthetic origin. The simplest of these, $(-)-(S)$ guignardic acid (72) made up of a shikimate-derived phenylpropanoid and an oxidized isoprene moiety, has been found to occur in a fungal endophyte, Guignardia sp., of the Brazilian medicinal plant Spondias mombin. ${ }^{40}$ Jesterone (74a) and hydroxyjesterone (74b) are two isoprenyl-pentaketides reported from the host-selective endophytic fungus, Pestalotiopsis jesteri, isolated from Fragraea bodenii. ${ }^{54}$ Jesterone was found to possess significant inhibitory activity against oomycetes fungal pathogens, Pythium ultimum, 
Aphanomyces sp., Phytophthora citrophthora, and P. cinnamomi. The related antimycotic isoprenyl-heptaketide, ambuic acid (75), has been found to occur in several isolates of Pestalotiopsis sp. and Monochaetia sp. obtained as endophytes of plants collected in several major representative rainforests of the world ${ }^{56}$ Colletorin B (76a), and its chlorinated analog, colletochlorin B (76b), together with ilicicolins C (77a), E (77b), and F (77c), have been isolated from Nectria galligena, a fungus endophytic in apple tree (Malus $\mathrm{x}$ domestica). ${ }^{49}$ Ilicicolins $\mathrm{C}$ (77a) and $\mathrm{F}(\mathbf{7 7 c})$ were found to possess moderate antibacterial activity against Pseudomonas syringae, and colletochlorin B (76b), ilicicolins C (77a), and E (77b) were shown to be moderate inhibitors of the enzyme, acetylcholinesterase (AChE). Leptosphaerone (82) has a new carbon skeleton and is a metabolite of a Leptosphaeria sp. isolated from Artemisia annua. ${ }^{42 b}$ A new antibiotic, lactone S 39163/F-I (83), with in vitro and in vivo antimicrobial and antiviral (anti-herpes) activities, has been isolated from a Microsphaeropsis sp., an endophytic fungal strain occurring in the leaf tissue of Buxus sempervirens. ${ }^{45}$ Further investigation of Aspergillus parasiticus endophytic in the coastal redwood tree, Sequoia sempervirens, has yielded four additional new sequoiatones namely, sequoiatones $\mathrm{C}-\mathrm{F}(\mathbf{8 4 a}-\mathbf{8 4 d}),{ }^{24 a}$ and a new series of monascins, sequoiamonascins $\mathrm{A}$ (85a), B (85b), C (86), and D (87), ${ }^{24 b}$ all of which were found to be toxic to brine shrimp. Sequoiamonascins A and B were also shown to inhibit proliferation of cancer cell lines, MCF-7 (breast), NCI-H460 (non-small cell lung), and SF-268 (CNS glioma).

\section{Alkaloids and other $\mathbf{N}$-Containing Metabolites}

A variety of $N$-containing compounds are known to occur in plant-associated microorganisms and during the period covered by this review, 21 alkaloids $(\mathbf{8 8}-\mathbf{1 0 6})$, seven cytochalasins $(107-109)$, and nine cyclic peptides $(\mathbf{1 1 0}-\mathbf{1 1 2})$ have been isolated and characterized. The majority of alkaloids encountered in these organisms are derived from tryptophan and thus contain indole moieties. ${ }^{14}$ Aspernigrin A, previously isolated from a marine strain of Aspergillus niger ${ }^{32 \mathrm{c}}$ has been re-isolated from Cladosporium herbarum endophytic in Cynodon dactylon and its structure was revised as $\mathbf{8 8}{ }^{32 \mathrm{~b}}$ Another endophytic fungus, Aspergillus fumigatus, occuring in $C$. dactylon has afforded the new antifungal metabolite, asperfumoid (89). ${ }^{22 a}$ The nematicidal alkaloid, peniprequinolone (90), first isolated from the soil fungus Penicillium cf. simplicissimum, ${ }^{52 \mathrm{e}}$ has been found in $P$. janczewskii, a fungal endophyte of the Chilean gymnosperm, Prumnopitys andina. ${ }^{52 \mathrm{a}}$ It is noteworthy that peniprequinolone (90) has recently been encountered in a $P$. janczewskii strain collected from a marine sample. ${ }^{52 \mathrm{f}}$ Two indole-derived mycotoxins, fumigaclavine $\mathrm{C}$ (91) and fumitremorgin $\mathrm{C}(\mathbf{9 2})$, previously known from other grass endophytes, and from an Aspergillus fumigatus strain in molded silage, ${ }^{22 \mathrm{~b}}$ have been characterized from $A$. fumigatus endophytic in Cynodon dactylon and their antifungal activity has been demonstrated. ${ }^{22 \mathrm{a}} N^{\mathrm{a}}-$ Acetyl aszonalemin (LL-S490 $\beta$ ) (93) is a rare benzodiazepinedione found to occur in a strain of Aspergillus terreus isolated from the rhizosphere of Ambrosia ambrosoides. ${ }^{85}$ Reinvestigation of Nodulisporium sp., endophytic in Bontia daphnoides and known to produce the indole terpenoid, nodulisporic acid A (94), has afforded two novel insecticides, nodulisporic acid $A_{1}(\mathbf{9 5 a})$ and $A_{2}(\mathbf{9 5 b})$, that are structurally related to 94.50

Based on previous reports that some endophytes are capable of developing a biochemical ability to produce compounds similar or identical to those produced by the host plant, ${ }^{17,92}$ Barros and Rodrigues-Filho have investigated an Eupenicillium sp. endophytic in Murraya paniculata resulting in the isolation of alanditrypinone (96), alantryphenone (97), alantrypinene (98), and alantryleunone (99), four members of the rare class of spiroquinazoline alkaloids. ${ }^{36}$ Their previous work on the host plant, M. paniculata, has failed to detect any alkaloids but has resulted in the isolation of phytoalexin-like metabolites including highly oxygenated and alkylated coumarins and flavonoids, accumulation of which may be related to fungal infestation. Members of a rare class of cytotoxic alkaloids, 
asterriquinones D (100a) and C-1 (100b), have been reported from a strain of Aspergillus terreus inhabiting the rhizosphere of the Sonoran desert cactus, Opuntia versicolor. ${ }^{87 \text { a }}$ The co-occurrence in this fungal strain of the new spirodione alkaloid, asterredione (102), has led to the proposition that it is biogenetically derived from asterriquinone $\mathrm{D}(\mathbf{1 0 0 a})$ by a hitherto unknown hydroperoxy-mediated $p$-benzoquinone ring contraction. In an extensive search for natural product-based antidiabetic agents capable of mimicking insulin activity, Salituro et al. screened over 5000 microbial extracts of which about 1500 were derived from endophytic fungal strains. ${ }^{59}$ Bioactivity-guided fractionation of a moderately active extract obtained from Pseudomassaria sp. endophytic in an unidentified plant from the Democratic Republic of Congo has afforded demethylasterriquinone B1 (DMAQ-B1) (100c) as the active compound. Oral administration of DMAQ-B1 resulted in significant lowering of the glucose levels in two mouse models of diabetes. Two additional asterriquinones (100d and $\mathbf{1 0 0 e})$ and three of their derivatives $(\mathbf{1 0 3}$ - 105) thought to be "artifacts" have also been characterized from this endophyte. ${ }^{59}$ However, it is possible that $\mathbf{1 0 3}-\mathbf{1 0 5}$ are genuine metabolites arising from DMAQ-B1 (100c) as a result of enzymatic hydroxylation, epoxidation, and hydroperoxy-mediated $p$-benzoquinone ring contraction ${ }^{87 a}$ (Figure $\mathrm{S} 1$, Supporting Information). Two new antibiotic alkaloids, pyrrocidines A (106a) and B (106b), based on rare 13-membered macrocyclic rings, previously reported from an unidentified fungal strain, have been found to occur in the maize endophyte, Acremonium zeae. ${ }^{21}$ It has been shown that this endophyte interferes with colony growth of kernel rotting and mycotoxin producing fungi, Aspergillus flavus and Fusarium verticillioides in cultural pairings and produced pyrrocidines, suggesting that $A$. zeae is a "protective endophyte" of maize.

A series of new weakly cytotoxic cytochalasins, aspochalasins I (107a), J (107b), and K (108a) together with four known members of this series, aspochalasins C (109a), D (109b), E (108b), and TMC-169 (109c), have been isolated from Aspergillus flavipes inhabiting the rhizosphere of Ericameria laricifolia. ${ }^{86}$ Plant-associated microorganisms are also known to produce a variety of bioactive cyclic peptides. Among these, diketopiperizines (e.g. 110a $\mathbf{1 1 0 g}$ ) are the most common. The sulfur-containing diketopiperizine, gliovictin (111), has been isolated from Penicillium janczewskii endophytic in Prumnopitys andina. ${ }^{52}$ Investigation of an unidentified fungal strain (No. 2524) endophytic in the seed of the mangrove plant, Avicinnia marina, has led to the characterization of the new cyclic pentapeptide $\mathbf{1 1 2}$ with no discernible inhibitory activity towards proliferating cancer cell lines. ${ }^{71}$

\section{Some Implications of the Occurrence of Plant-associated Microorganisms and Their Metabolites}

The ability of organisms to form long-term, intimate, and diverse relationships with each other, as is the case with plants and their associated microorganisms, is currently recognized as a common ecological phenomenon. According to Siegel and Bush" ${ }^{93}$ "symbiosis, as a general term, does not imply detriment or benefit, but rather that the outcome (net effect) of species interaction exists within a symbiotic continuum or 'species interaction grid' that includes agonism (predation and disease) and mutualism (benefits for both species)." Examples of species interaction that span the symbiotic continuum affecting the ecological fitness of the host, include endophytic fungi of the genus Epichloë (Clavicipitaceae) and some grass species (Poaceae). For this symbiosis, a mutualism-parasitism continuum has recently been proposed. ${ }^{94}$ Infected grasses rarely show external signs of the endophyte, but may have enhanced ecological fitness, ${ }^{95}$ and tolerance to both biotic and abiotic environmental stresses. ${ }^{96}$ It is noteworthy that in many cases the tolerance to biotic stresses have been correlated with natural products, especially bioprotective pyrrolizidine, indole and pyrrolopyrazine alkaloids, produced by the grass-endophyte associations that act in a 
defensive mutualism. ${ }^{96,97}$ Various endophytes have been found to play important roles in host plant vitality. Production of two macrocyclic alkaloids, pyrrocidines A (106a) and B (106b), with antibiotic activity, by the endophytic fungus, Acremonium zeae, has been implicated recently in the protection of its host, maize, against the pathogenic and mycotoxin producing fungi Aspergillus flavus and Fusarium verticillioides. ${ }^{21}$ It is significant that the majority of natural products occurring in endophytic microorganisms have been shown to have antimicrobial activity (Table 1) and in many cases these have been implicated in protecting the host plant against phytopathogenic microorganisms.

The recent observation of extensive colonization of native grasses growing in semi-arid rangelands of the southwestern U.S. by dark septate endophytic fungi and their atypical morphology has led to the suggestion that these fungi enhance the performance of their hosts, thus promoting their survival in this stressed environment. ${ }^{98}$ In a study involving the grass species, Dichanthelium lanuginosum (Poaceae), collected from geothermal soils in Lassen Volcanic and Yellowstone National Parks, it was found that an endophytic fungal isolate Curvularia sp. confered thermotolerance to the host, probably as a result of the production of cell wall melanin that may dissipate heat along the fungal hyphae and/or complex with oxygen radicals generated during heat stress. ${ }^{99 a}$ It has recently been demonstrated that this fungal endophyte is also capable of thermoprotecting other plants including tomato, watermelon, and wheat. ${ }^{99 \mathrm{~b}}$ Several Sonoran desert plant-associated fungi that produce heat shock protein-90 (Hsp90) inhibitors were recently identified in an extensive program of screening these organisms for biologically relevant small molecule natural products. ${ }^{30} \mathrm{In}$ an attempt to investigate if production of these small molecule secondary metabolites by fungal symbionts might enhance the stress tolerance of their host plants by inducing the evolutionarily conserved heat shock response, monocillin I (30a) elaborated by the rhizosphere fungus, Paraphaeosphaeria quadriseptata ${ }^{89}$ was found to bind to Hsp90 and induce components of the heat shock response at the transcriptional and translational levels leading to the acquisition of a thermotolerant phenotype in seedlings of the model plant Arabidopsis thaliana; more significantly, it was also found that the growth of $A$. thaliana with the fungus can also confer thermotolerance. ${ }^{100}$ These findings are consistent with previous observations (see above) that plant-fungal symbiosis can enhance thermotolerance in the wild ${ }^{99}$ and they define a specific molecular mechanism of potential agricultural significance whereby mutualistic fungi may manipulate plant Hsp90 to enhance host plant survival in stressful environments.

In a recent study of beneficial plant-microbe interactions, the cultivable plant-rootcolonizing endophytic fungus, Piriformospora indica (Basidiomycetes), discovered in the Indian Thar desert, was found to have significant growth-promoting effects on a variety of crop plants. ${ }^{101}$ When the cereal model plant barley (Hordeum vulgare L.) was infected with $P$. indica it was found to have several beneficial effects including the growth-promoting activity resulting in enhanced barley grain yield, amended tolerance to mild salt stress, and conferred resistance in barley against root and leaf pathogens. ${ }^{102}$ Further studies have demonstrated that the systematically altered "defense readiness" of barley by this endophyte is associated with an elevated antioxidative capacity due to an activation of the glutathioneascorbate cycle, and that the endophyte might induce systemic disease resistance by an as yet unknown signaling pathway, probably involving a small molecule natural product. ${ }^{103}$ Based on the data obtained, these authors have suggested consideration of $P$. indica as a tool for sustainable agriculture.

\section{Supplementary Material}

Refer to Web version on PubMed Central for supplementary material. 


\section{Acknowledgments}

The author is thankful to his collaborators, Drs. Luke Whitesell, Stan Faeth, Leland Pierson III, Elizabeth Pierson, Linda Meade-Tollin, and Hans VanEtten, and coworkers, Drs. Kithsiri Wijeratne, Tommy Turbyville, Bharat Bashyal, Jixun Zhan, Jian He, Jacqueline Takahashi, Priyani Paranagama, Guang Zhou, Kamal Gunaherath, Mr. Christopher Seliga, Ms. Manping Liu, Ms. Anna Burns, Ms. Anne Fritz, and Ms. Libia Luevano, for their valuable contributions to the research programs on Sonoran desert plant-associated microorganisms. He is also thankful to Dr. Istvan Molnar for helpful discussions, and Ms. Jan Taylor and Mr. Christopher Seliga for their assistance in the preparation of this manuscript. The author expresses his appreciation to Arizona Biomedical Research Commission (grants 9014, 30004, 6015, and 0013) and NCI (grant R01 CA 90265), for providing financial support for some of the work reviewed.

\section{References and Notes}

1. Manly, SP.; Padmanabha, R.; Lowe, SE. Methods in Molecular Biology, Vol. 190, High Throughput Screening: Methods and Protocols. Janzen, WP., editor. Humana Press; New Jersey: 2002. p. 153-168.

2. Young P. ASM News. 1997; 63:417-421.

3. a Ward DM, Weller R, Bateson MM. Nature. 1990; 345:63-65. [PubMed: 1691827] b Torsvik V, Goksoyr J, Daae FL. Appl. Environ. Microbiol. 1990; 56:782-787. [PubMed: 2317046] c Stackbrandt E, Liesack W, Goebel BM. FASEB J. 1993; 7:232-236. [PubMed: 8422969] d Torsvik V, Sorheim R, Goksoyr J. J. Ind. Microbiol. 1996; 17:170-178.e Hugenhotz P, Goebel BM, Pace NR. J. Bacteriol. 1998; 180:4765-4774. [PubMed: 9733676]

4. Zengler K, Toledo G, Rappe M, Elkins J, Mathur E, Short JM, Keller M. Proc. N. Y. Acad. Sci. 2002; 99:15681-15686.

5. a Brady SF, Chao CJ, Handelsman J, Clardy J. Org. Lett. 2001; 3:1981-1984. [PubMed: 11418029] b Brady SF, Clardy J. J. Am. Chem. Soc. 2000; 122:12903-12904.c Brady SF, Chao CJ, Clardy J. J. Am. Chem. Soc. 2002; 124:9968-9969. [PubMed: 12188643]

6. Wilkinson RA, Strobel G, Stierle A. J. Nat. Prod. 1999; 62:358-360. [PubMed: 10075787]

7. a Bode HB, Bethe B, Hofs R, Zeek A. ChemBioChem. 2002; 3:619-627. [PubMed: 12324995] b Grond S, Papastavrou I, Zeeck A. Eur. J. Org. Chem. 2002:3237-3242.c Puder C, Loya S, Hizi A, Zeeck A. J. Nat. Prod. 2001; 64:42-45. [PubMed: 11170664] d Bode HB, Walker M, Zeeck A. Eur. J. Org. Chem. 2000:3185-3193.

8. a Clay K, Holah J. Science. 1999; 285:1742-1744. [PubMed: 10481011] b Wang J, Huang Y, Fang M, Zhang Y, Zheng Z, Zhao Y, Su W. FEMS Immun. Med. Microbiol. 2002; 34:51-57.c Betina Y. Folia Microbiol. 1992; 37:3-11. [PubMed: 1505860] d Vurro M, Evidente A, Andolfi A, Zonuo MC, Giordano F, Motta A. Plant Sci. 1998; 138:67-79.e Zhu JW, Nagasawa H, Nagura F, Mohamad SB, Uto Y, Okura K, Hori H. Biorg. Med. Chem. 2000; 8:455-463.f Ritzenthaler C, Nebenführ A, Movafeghi A, Stussi-Garaud C, Behnia L, Pimpl P, Staehelin LA, Robinson DG. Plant Cell. 2002; 14:237-261. [PubMed: 11826310]

9. a Pirozynski KA, Malloch DW. BioSystems. 1975; 6:153-164. [PubMed: 1120179] b Blackwell M. Science. 2000; 289:1884-1885. [PubMed: 11012361]

10. Dreyfuss, MM.; Chapela, IH. The Discovery of Natural Products with Therapeutic Potential. Gullo, VP., editor. Butterworth-Heinemann; Boston: 1994. p. 49-79.

11. Carroll GC. Ecology. 1988; 69:2-9.

12. Freeman EM. Phil. Trans. Royal. Soc. Lond. [Biol.]. 1904; 196:1.

13. Gusman J, Vanhaelen M. Recent Res. Devel. Phytochem. 2000; 4:187-206.

14. Tan RX, Zou WX. Nat. Prod. Rep. 2001; 18:448-459. [PubMed: 11548053]

15. Schulz B, Boyle C, Draeger S, Rommert A-K, Krohn K. Mycol. Res. 2002; 106:996-1004.

16. a Strobel GA. Crit. Rev. Biotech. 2002; 22:315-333.b Strobel GA. Agro-Food-Industry Hi-Tech. 2004; 13:12-14.

17. Strobel GA. Microbes Infect. 2003; 5:535-544. [PubMed: 12758283]

18. a Strobel G, Daisy B. Microbiol. Mol. Biol. Rev. 2003; 67:491-502. [PubMed: 14665674] b Strobel G, Daisy B, Castillo U, Harper J. J. Nat. Prod. 2004; 67:257-268. [PubMed: 14987067] c Takeda N, Sato H, Suenaga K, Arimoto H, Yamada K, Ueda K, Uemura D. Tetrahedron Lett. 
1999; 40:6309-6312.d Thaning C, Welch CJ, Borowicz JJ, Hedman R, Gerhardson B. Soil Biol. Biochem. 2001; 33:1817-1826.

19. Wang Y, Xiao Y. Shengwuxue Zashi. 2004; 21:1-5.

20. Stierle, AA.; Stierle, DB. Studies in Natural Products Chemistry, Vol. 24, Bioactive Natural Products (Part E). Atta-ur-Rahman, editor. Elsevier; Amsterdam: 2000. p. 933-977.

21. a Wicklow DT, Roth S, Deyrup ST, Gloer JB. Mycol. Res. 2005; 109:610-618. [PubMed: 16018316] b He H, Yang HY, Bigelis R, Solum EH, Greenstein M, Carter GT. Tetrahedron Lett. 2002; 43:1633-1636.

22. a Liu JY, Song YC, Zhang Z, Wang L, Guo ZJ, Zou WX, Tan RX. J. Biotechnol. 2004; 114:279287. [PubMed: 15522437] b Cole RJ, Kirksey JW, Dorner JW, Wilson DN, Johnson JC, Johnson JAN, Bedell DM, Springer JP, Chexal KK, Clardy JC, Cox RH. J. Agric. Food Chem. 1977; 25:826-830. [PubMed: 328548]

23. Song YC, Li H, Ye YH, Shan CY, Yang YM, Tan RX. FEMS Microbiol. Lett. 2004; 241:67-72. [PubMed: 15556711]

24. a Stierle AA, Stierle DB, Bugni T. J. Nat. Prod. 2001; 64:1350-1353. [PubMed: 11678666] b Stierle DB, Stierle AA, Bugni T. J. Org. Chem. 2003; 68:4966-1969. [PubMed: 12790612]

25. a Li Y, Song YC, Liu JY, Ma YM, Tan RX. World J. Microbiol. Biotech. 2005; 21:553-558.b Matsueda S, Katsukara Y. Chem. Ind. 1985; 12:411.

26. Stierle DB, Stierle AA, Kunz A. J. Nat. Prod. 1998; 61:1277-1278. [PubMed: 9784167]

27. Song YC, Huang WY, Sun C, Wang FW, Tan RX. Biol. Pharm. Bull. 2005; 28:506-509. [PubMed: 15744078]

28. Yu N, Guo S, Xiao S, Xie F. Zhogguo Zhongyao Zashi. 2002; 27:204-208.

29. Rizzo I, Varsavsky E, Haidukowski M, Frade H. Toxicon. 1997; 35:753-757. [PubMed: 9203300]

30. Turbyville TJ, Wijeratne EMK, Liu MX, Burns AM, Seliga CJ, Leuvano LA, David CL, Faeth SH, Whitesell L, Gunatilaka AAL. J. Nat. Prod. 2006; 69:xx-xx.

31. Bashyal BP, Wijeratne EMK, Faeth SH, Gunatilaka AAL. J. Nat. Prod. 2005; 68:724-728. [PubMed: 15921417]

32. a Cutler HG, Crumley FG, Cox RH, Hernandez O, Cole RJ, Domer JW. J. Agric. Food Chem. 1979; 27:592-595. [PubMed: 447931] b Ye YH, Zhu HL, Song YC, Liu JY, Tan RX. J. Nat. Prod. 2005; 68:1106-1108. [PubMed: 16038560] c Hiort J, Maksimenka K, Reichart M, PeroviaeOttstadt S, Lin WH, Wray V, Steube K, Schaumann K, Weber H, Proksch P, Ebel R, Müller WEG, Bringmann G. J. Nat. Prod. 2004; 67:1532-1543. [PubMed: 15387655]

33. Wang M, Chen S, Yan S, Huo. J. Nanjing Shida Zuebao, Ziran Kexueban. 2003; 26:106-110.

34. a Brady SF, Wagenaar MM, Singh MP, Janso JE, Clardy J. Org. Lett. 2000; 2:4043-4046. [PubMed: 11112639] b Brady SF, Singh MP, Janso JE, Clardy J. Org. Lett. 2000; 2:4047-4049. [PubMed: 11112640]

35. a Xu Q, Wang J, Huang Y, Zheng Z, Song S, Zhang Y, Su W. Acta Oceanol. Sinica. 2004; 23:541-547.b Xu Q, Huang Y, Zheng Z, Song S, Zhang Y, Su W. Xiamen Daxue Xuebao, Ziran Kexueban. 2005; 44:425-428.

36. Barros FAP, Rodriguez-Filho E. Biochem. Syst. Ecol. 2005; 33:257-268.

37. Zhang L, Guo B, Li H, Zeng S, Shao H, Gu S, Wei R. Zhongcaoyao. 2000; 31:805-807.

38. Shu RG, Wang FW, Yang YM, Liu YX, Tan RX. Lipids. 2004; 39:667-673. [PubMed: 15588024]

39. Krohn K, Biele C, Drogies K-H, Steingrover K, Aust H-J, Draeger S, Schulz B. Eur. J. Org. Chem. 2002; 14:2331-2336.

40. Rodrigues-Heerklotz KF, Drandarov K, Heerklotz J, Hesse M, Werner C. Helv. Chim. Acta. 2001; 84:3766-3772.

41. Pelaez F, Cabello A, Platas G, Diez MT, Gonzalez del Val A, Basilio A, Martan I, Vicente F, Bills GF, Giacobbe RA, Schwartz RE, Onishi JC, Meinz MS, Abruzzo GK, Flattery AM, Kong L, Kurtz MB. Syst. Appl. Microbiol. 2000; 23:333-343. [PubMed: 11108011]

42. a Liu J-Y, Liu C-H, Zou W-X, Tan R-X. Helv. Chim. Acta. 2003; 86:657-660.b Liu J-Y, Liu C-H, Zou W-X, Tian X, Tan R-X. Helv. Chim. Acta. 2002; 85:2664-2667.

43. Schwarz M, Koepcke B, Weber RWS, Sterner O, Anke H. Phytochemistry. 2004; 65:2239-2245. [PubMed: 15587708] 
44. Hormazahal E, Schmeda-Hirschmann G, Astudillo L, Rodriguez J, Theoduloz C. Z. Naturforsch., C: J. Biosci. 2005; 60C:11-21.

45. Tscherter, H.; Hofmann, H.; Ewald, R.; Dreyfuss, MM. 1988. U.S. Patent No. 4,753,959

46. a Strobel GA, Dirkse E, Sears J, Markworth C. Microbiology. 2001; 147:2943-2950. [PubMed: 11700345] b Ezra D, Hess WM, Strobel GA. Microbiology. 2004; 150:4023-4031. [PubMed: 15583155] c Atmosukarto I, Castillo U, Hess WM, Sears J, Strobel G. Plant Sci. 2005; 169:854 861.

47. Krohn K, Florke U, Rao MS, Steingrover K, Aust H-J, Draeger S, Schulz B. Nat. Prod. Lett. 2001; 15:353-361. [PubMed: 11841120]

48. a Krohn K, Florke U, John M, Root N, Steingrover K, Aust H-J, Draeger S, Schulz B, Antus S, Simonyi M, Zsila F. Tetrahedron. 2001; 57:4343-4348.b Singh SB, Zink DL, Liesch JM, Ball RG, Goetz MA, Bolessa EA, Giacobbe RA, Silverman KC, Bills GF, Palaez F, Cascales C, Gibbs JB, Lingman RB. J. Org. Chem. 1994; 59:6296-6302.

49. Gutierrez M, Theoduloz C, Rodriguez J, Lolas M, Schmeda-Hirschmann G. J. Agric. Food Chem. 2005; 53:7701-7708. [PubMed: 16190620]

50. a Hensens OD, Ondeyka JG, Dombrowski AW, Ostlind DA, Zink DL. Tetrahedron Lett. 1999; 40:5455-5458.b Ondeyka JG, Helms GL, Hensens OD, Goetz MA, Zink DL, Tsipouras A, Shoop WL, Slayton L, Dombrowski AW, Polishook JD, Ostlind DA, Tsou NN, Ball RG, Singh SB. J. Am. Chem. Soc. 1997; 119:8809-8816.

51. Zeng S, Shao H, Zhang L. Weishengwuxue Zashi. 2004; 24:1-2.

52. a Schmeda-Hirschmann G, Hormazabal E, Astudillo L, Rodriguez J, Theoduloz C. World J. Microbiol. Biotech. 2005; 21:27-32.b Dai JR, Carte B, Sidebottom P, Sek AL, Ng S, Huang Y, Butler M. J. Nat. Prod. 2001; 64:125-126. [PubMed: 11170686] c Krohn K, Bahmasari R, Florke V, Ludewig K, Kliche-Spory C, Michel A, Aust H, Draeger S, Schulz B, Antus S. Phytochemistry. 1997; 45:313-320. [PubMed: 9141717] d Parisi A, Piatelli M, Tringale C, Magnano G.

Phytochemistry. 1993; 32:865-867.e Kusano M, Koshino H, Uzawa J, Fujioka S, Kawano T, Kimura Y. Biosci. Biotech. Biochem. 2000; 64:2559-2568.f He J, Lion U, Sattler I, Gollmick FA, Grabley S, Cai J, Meiners M, Schunke H, Shaumann K, Dechert U, Krohn M. J. Nat. Prod. 2005; 68:1397-1399. [PubMed: 16180822]

53. a Kim S, Shin D-S, Lee T, Oh K-B. J. Nat. Prod. 2004; 67:448-450. [PubMed: 15043428] b Shin D-S, Oh M-N, Yang H-C, Oh K-B. J. Microbiol. Biotech. 2005; 15:216-220.

54. Li JY, Strobel GA. Phytochemistry. 2001; 57:261-265. [PubMed: 11382242]

55. Harper JK, Arif AM, Ford EJ, Strobel GA, Porco JA, Tomer DP, O'Neill KL, Grant DM. Tetrahedron. 2003; 58:2471-2476.

56. Li JY, Harper JK, Grant DM, Tombe BO, Bashyal B, Hess WM, Strobel GA. Phytochemistry. 2001; 56:463-468. [PubMed: 11261579]

57. Weber D, Sterner O, Anke T, Gorzalczancy S, Martino V, Acevedo C. J. Antibiot. 2004; 57:559_ 563. [PubMed: 15580955]

58. Suriyanarayanan TS, Ravishankar JP, Venkatesan G, Murali TS. Mycological Res. 2004; 108:974978.

59. Salituro GM, Pelaez F, Zhang BB. Recent Prog. Hormone Res. 2001; 56:107-126.

60. Ma YM, Li Y, Liu JY, Song YC, Tan RX. Fitoterapia. 2004; 75:451-456. [PubMed: 15261382]

61. Strobel G, Li JY, Sugawara F, Koshino H, Harper J, Hess WM. Microbiology. 1999; 145:35573564. [PubMed: 10627053]

62. Krohn K, Sohrab MH, Aust H-J, Draeger S, Schulz B. Nat. Prod. Res. 2004; 18:277-285. [PubMed: 15143840]

63. Taechowisan T, Lu C, Shen Y, Lumyong S. Microbiology. 2005; 151:1691-1695. [PubMed: 15870476]

64. Guan S, Suttler I, Lin W, Guo D, Grabley S. J. Nat. Prod. 2005; 68:1198-1200. [PubMed: 16124760]

65. Castillo UF, Strobel GA, Ford EJ, Hess WM, Porter H, Jensen JB, Albert H, Robison R, Condron MAM, Teplow DB, Stevens D, Yaver D. Microbiology. 2002; 148:2675-2685. [PubMed: 12213914] 
66. Castillo U, Harper JK, Strobel GA, Sears J, Alesi K, Ford E, Lin J, Hunter M, Maranta M, Ge H, Yaver D, Jensen JB, Porter H, Robison R, Miller D, Hess WM, Condron M, Teplow D. FEMS Microbiol. Lett. 2003; 234:183-190. [PubMed: 12892881]

67. Ezra D, Castillo UF, Strobel GA, Hess WM, Porter H, Jensen JB, Condron MAM, Teplow DB, Sears J, Maranta M, Hunter M, Weber B, Yaver D. Microbiology. 2004; 150:785-793. [PubMed: 15073289]

68. a Brady SF, Singh MP, Janso JE, Clardy J. J. Am. Chem. Soc. 2000; 122:2116-2117.b Brady SF, Bondi SM, Clardy J. J. Am. Chem. Soc. 2001; 123:9900-9901. [PubMed: 11583556] c Singh MP, Janso JE, Luckman SW, Brady SF, Clardy J, Greenstein M, Maiese WM. J. Antibiot. 2000; 53:256-261. [PubMed: 10819296]

69. a Chen G, Lin Y, Wen L, Vrijmoed LLP, Gareth Jones EB. Tetrahedron. 2003; 59:4907-4909.b Cai P, McPhail AT, Krainer E, Katz B, Pearce C, Boros C, Caceres B, Smith D, Houck DR. Tetrahedron Lett. 1999; 40:1479-1482.

70. Findlay JA, Li G, Miller JD, Womiloju TO. Can. J. Chem. 2003; 81:284-292.

71. Li H-J, Lin Y-C, Yao J-H, Vrijmoed LLP, Jones EBG. J. Asian Nat. Prod. Res. 2004; 6:185-191. [PubMed: 15224415]

72. Lin Y, Wan J, Zhou S, Jones G. Chem. J. Internet. 2001; 3:30. (http://www.chemistrymag.org/cji/ 2001/037030ne.htm).

73. Wu X, Li M, Hu G, Lin Y, Vrijmoed LLP. Zhonghan Daxue Xuebao, Ziran Kaxueban. 2002; 41:34-36.

74. Zhu F, Lin Y-C, Zhou S-N, Vrijmoed LLP. Zhongshan Daxue Xuebao, Ziran Kexueban. 2003; 42:52-54.

75. Singh BK, Millard P, Whiteley AS, Murrell JC. Trends in Microbiol. 2004; 12:386-393.

76. Smalla K, Wachtendorf U, Heuer H, Liu W-T, Forney L. Appl. Environ. Microbiol. 1998; 64:1220-1225. [PubMed: 16349535]

77. Lynch JM, Whipps JM. Plant Soil. 1990; 129:1-10.

78. Baudoin E, Benizri E, Guckert A. Soil Biol. Biochem. 2003; 35:1183-1192.

79. a Whipps JM. J. Experimental Botany. 2001; 52:487-511.b Kent AD, Triplett EW. Ann. Rev. Microbiol. 2002; 56:211-236. [PubMed: 12142496] c Morello JE, Pierson EA, Pierson LS III. Appl. Environ. Microbiol. 2004; 70:3103-3109. [PubMed: 15128573]

80. Trejo-Estrada SR, Paszczynski A, Crawford DL. J. Ind. Microbiol. Biotech. 1998:81-90.

81. a Rovira AD. Plant Soil. 1956; 47:178-194.b Berg G, Zachow C, Lottmann J, Gotz M, Costa R, Smalla K. Appl. Environ. Microbiol. 2005; 71:4203-4213. [PubMed: 16085804]

82. a Rovira AD. Plant Soil. 1959; 49:53-64.b Rovira, AD. Ecology of Soilborne Pathogens - Prelude to Biological Control. Baker, KF.; Snyder, WC., editors. University of California Press; Berkeley, CA: 1965. p. 170-186.

83. Grayston SJ, Wang S, Campbell CD, Edwards AC. Soil Biol. Biochem. 1998; 30:369-378.

84. Basil AJ, Strap JL, Knotek-Smith HM, Crawford DL. J. Indust. Microbiol. Biotech. 2004; 31:278288.

85. a He J, Wijeratne EMK, Bashyal BP, Zhan J, Seliga CJ, Liu MX, Pierson EE, Pierson LS, VanEtten HD, Gunatilaka AAL. J. Nat. Prod. 2004; 67:1985-1991. [PubMed: 15620238] b Kobayashi A, Hino T, Yata S, Itoh TJ, Sato H, Kawazu K. Agric. Biol. Chem. 1988; 52:31193123.c Matsushita, N.; Akinaga, S.; Agatsuma, T. 2004. International Patent No. WO 2004/024141

86. Zhou G-X, Wijeratne EMK, Bigelow D, Pierson LS III, VanEtten HD, Gunatilaka AAL. J. Nat. Prod. 2004; 67:328-332. [PubMed: 15043404]

87. a Wijeratne EMK, Turbyville TJ, Zhang Z, Bigelow D, Pierson LS III, Whitesell L, Canfield LM, Gunatilaka AAL. J. Nat. Prod. 2003; 66:1567-1573. [PubMed: 14695798] b Turbyville TJ, Wijeratne EMK, Whitesell L, Gunatilaka AAL. Mol. Cancer Ther. 2005; 4:1569-1576. [PubMed: 16227407]

88. Wijeratne, EMK.; Turbyville, TJ.; Fritz, A.; Gunatilaka, AAL. Abs. Am. Soc. Pharmacog. 46th Annual Meeting; Corvallis, OR. July 23-27, 2005; Abstract P: 192 
89. a Wijeratne EMK, Carbonezi CA, Takahashi JA, Seliga CJ, Turbyville TJ, Pierson EE, Pierson LS III, VanEtten HD, Whitesell L, Bolzani V. da S. Gunatilaka AAL. J. Antibiot. 2004; 57:541-546. [PubMed: 15515894] Wijeratne, EMK.; Gunatilaka, AAL. Abs. Internat. Congress on Nat. Prod. Res.; Phoenix, AZ. July 31-Aug. 4, 2004; Abstract P: 406

90. Zhan J, Wijeratne EMK, Seliga CJ, Zhang J, Pierson EE, Pierson LS III, VanEtten HD, Gunatilaka AAL. J. Antibiot. 2004; 57:341-344. [PubMed: 15317106]

91. Dewick, PM. Medicinal Natural Products: A Biosynthetic Approach. John Wiley \& Sons; West Sussex, England: 1997. p. 109

92. Petrini O, Sieber TN, Toti L, Vivet O. Nat. Toxins. 1992; 1:185-196. [PubMed: 1344919]

93. Siegel, MR.; Bush, LP. Recent Advances in Phytochemistry, Vol. 30. Phytochemical Diversity and Redundancy in Ecological Interaction. Romeo, JT.; Saunders, JA.; Barbosa, P., editors. Plenum Press; New York: 1996. p. 81-119.

94. Muller CB, Krauss. J. Curr. Opin. Plant Biol. 2005; 8:450-456.

95. Clay, K. Biotechnology of Endophytic Fungi of Grasses. Bacon, CW.; White, JF., editors. CRC Press; Boca Raton, FL: 1994. p. 73-86.

96. Bush LP, Wilkinson HH, Schardl CL. Plant Physiol. 1997; 114:1-7. [PubMed: 12223685]

97. Clay K. Ecology. 1988; 69:10-16.

98. Barrow JR. Mycorrhiza. 2003; 13:239-247. [PubMed: 14593517]

99. a Redman RS, Sheehan KB, Stout RG, Rodriguez RJ, Henson JM. Science. 2002; 298:1581. [PubMed: 12446900] b Science. 2003; 301:1466. Anonymous.

100. Turbyville, TJ.; McLellan, CA.; Wijeratne, EMK.; Kerschen, A.; Vierling, E.; Quietsch, C.; Whitesell, L.; Gunatilaka, AAL. 2006. Manuscript in preparation

101. Varma A, Verma S, Sudha, Sahay N, Butehorn B, Franken P. Appl. Environ. Microbiol. 1999; 65:2741-2744. [PubMed: 10347070]

102. Waller F, Achatz B, Baltruschat H, Fodor J, Becker K, Fischer M, Heier T, Hückelhoven R, Neumann C, von Wetstein D, Franken P, Kogel K-H. Proc. Nat. Acad. Sci. U.S.A. 2005; 102:13386-13391.

103. Mabberley, DJ. The Plant-book, A Portable Dictionary of the Vascular Plants. 2nd Edit.. Cambridge University Press; Cambridge, UK: 1997. 


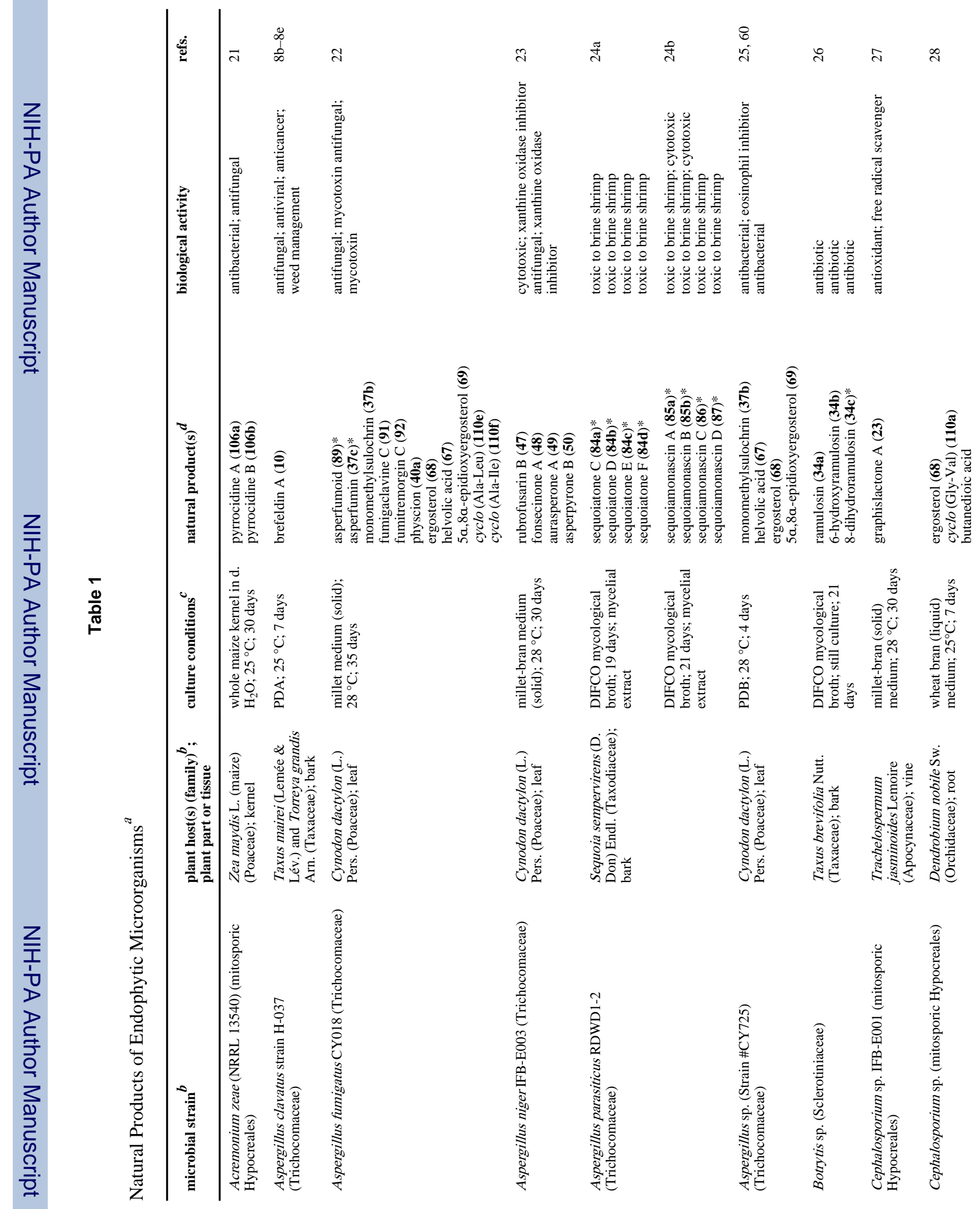




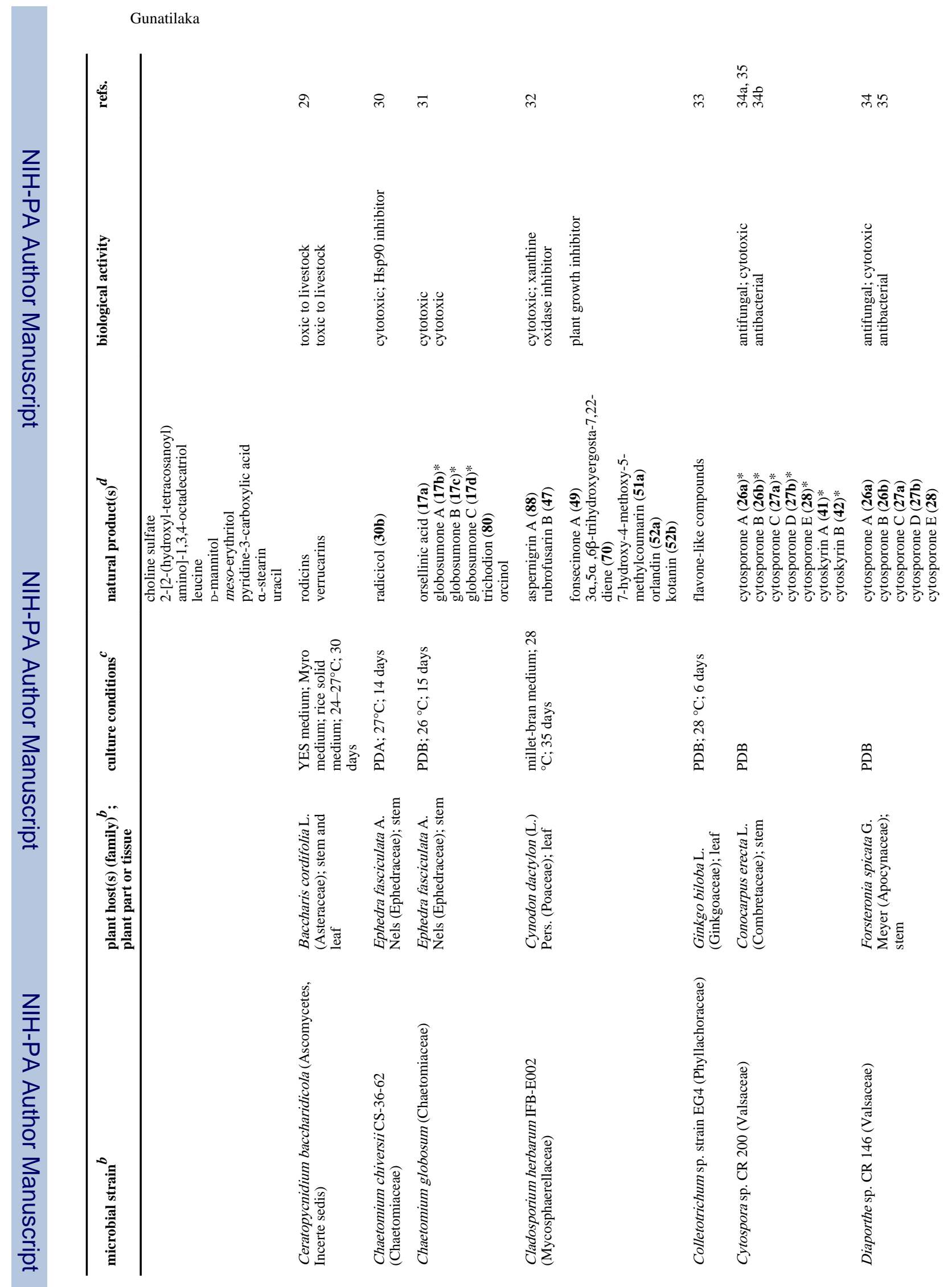

J Nat Prod. Author manuscript; available in PMC 2012 May 29. 


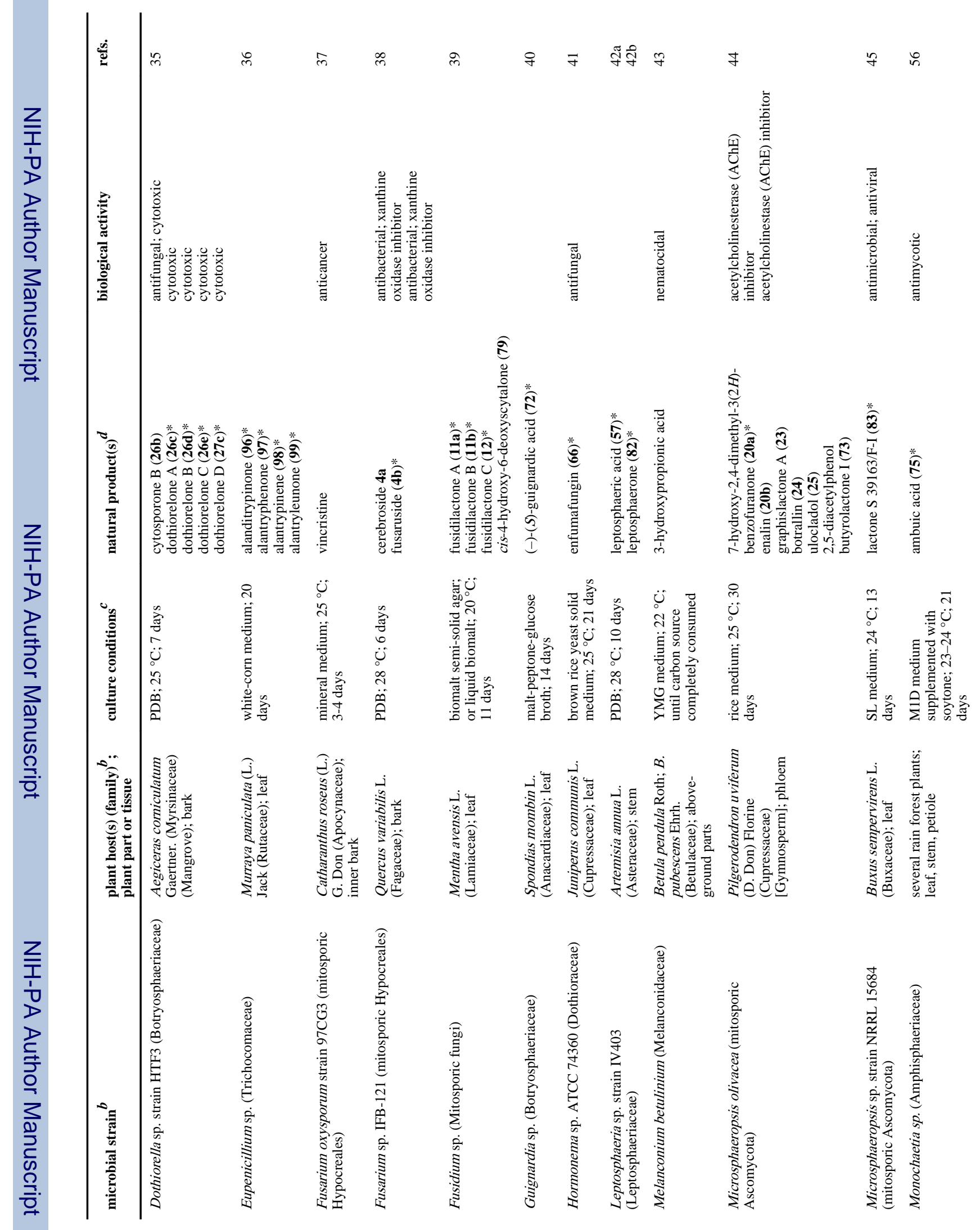




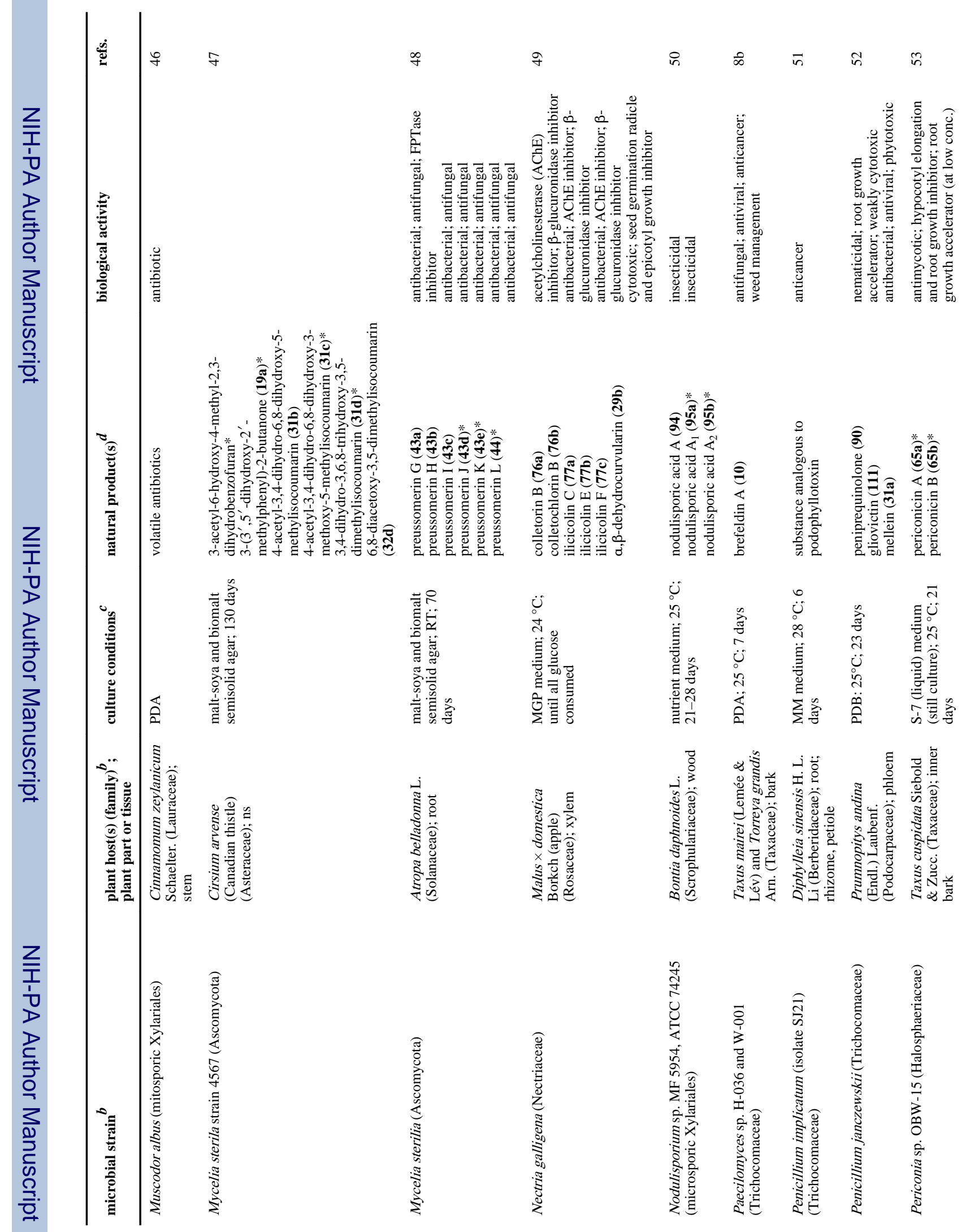




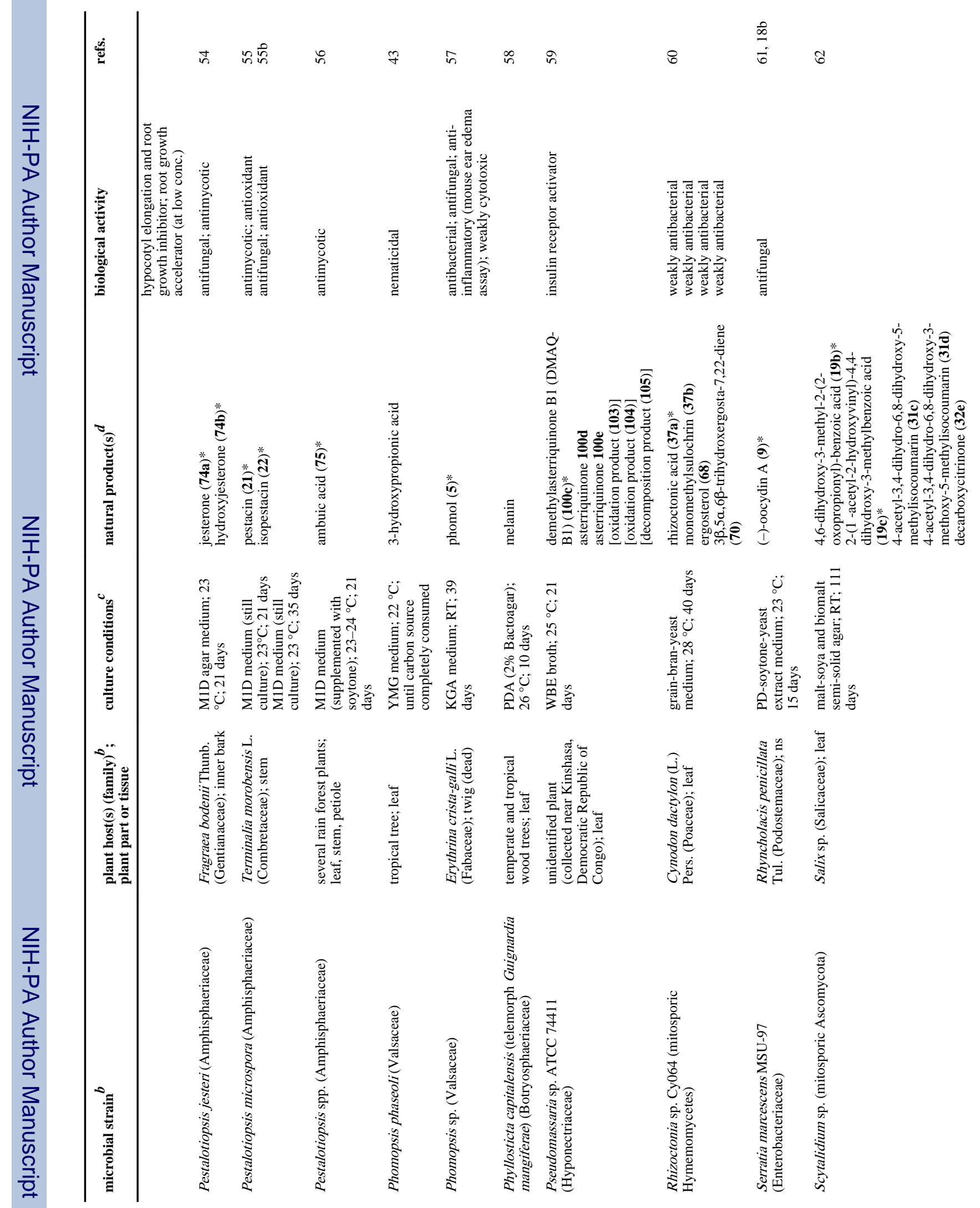




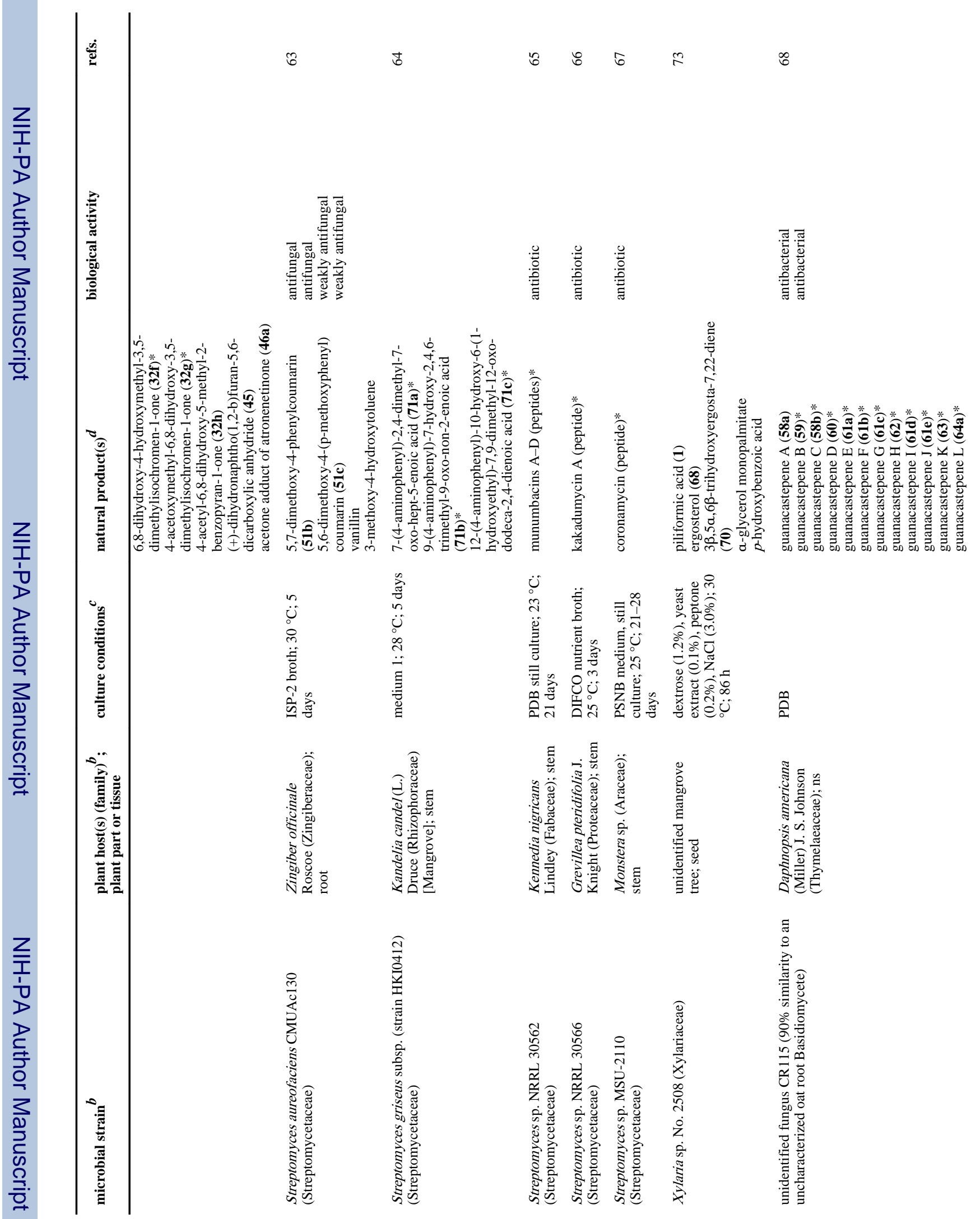



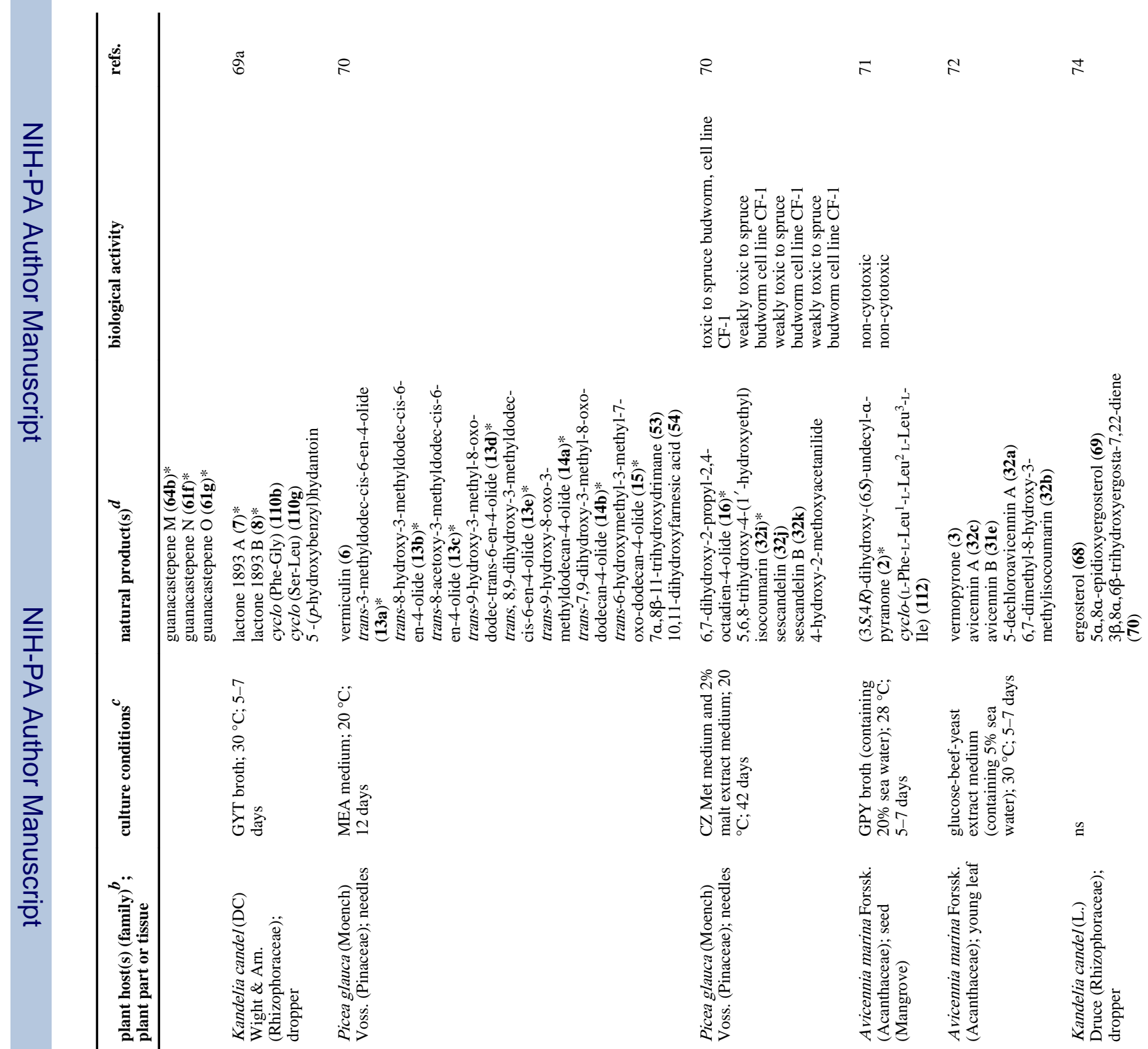

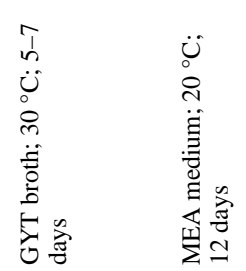
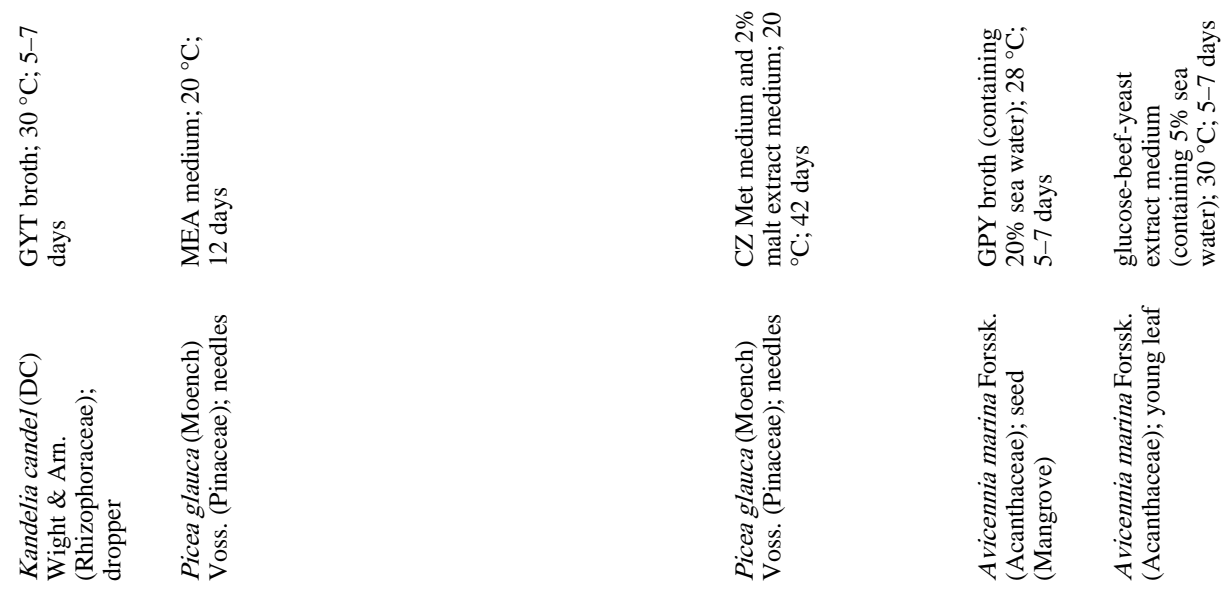

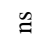
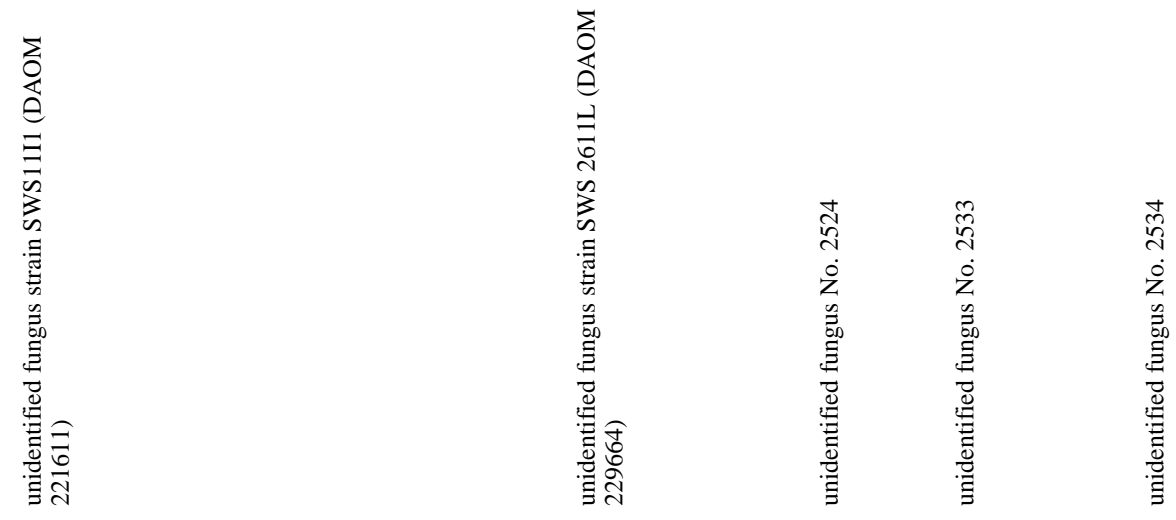


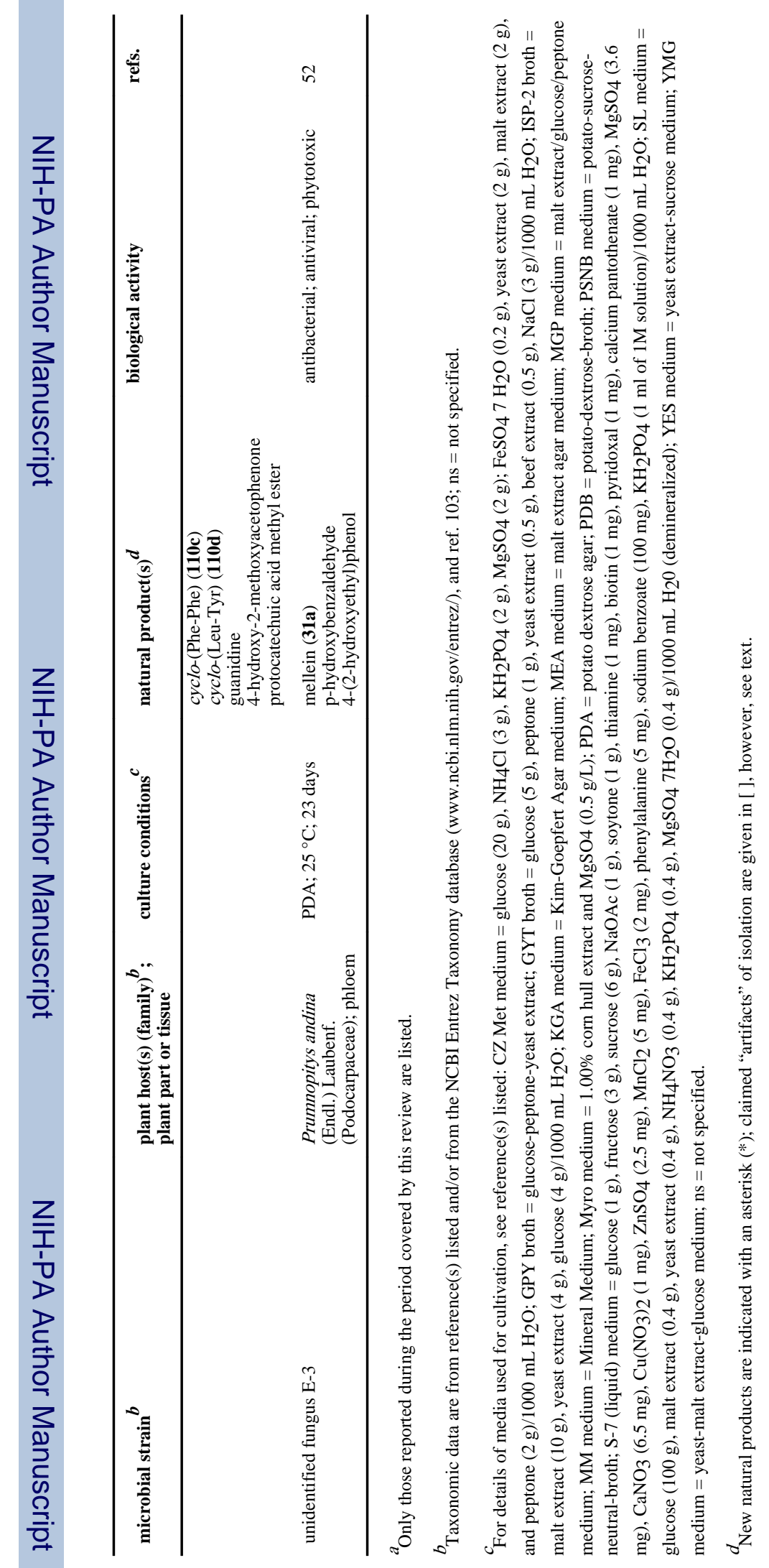

J Nat Prod. Author manuscript; available in PMC 2012 May 29. 


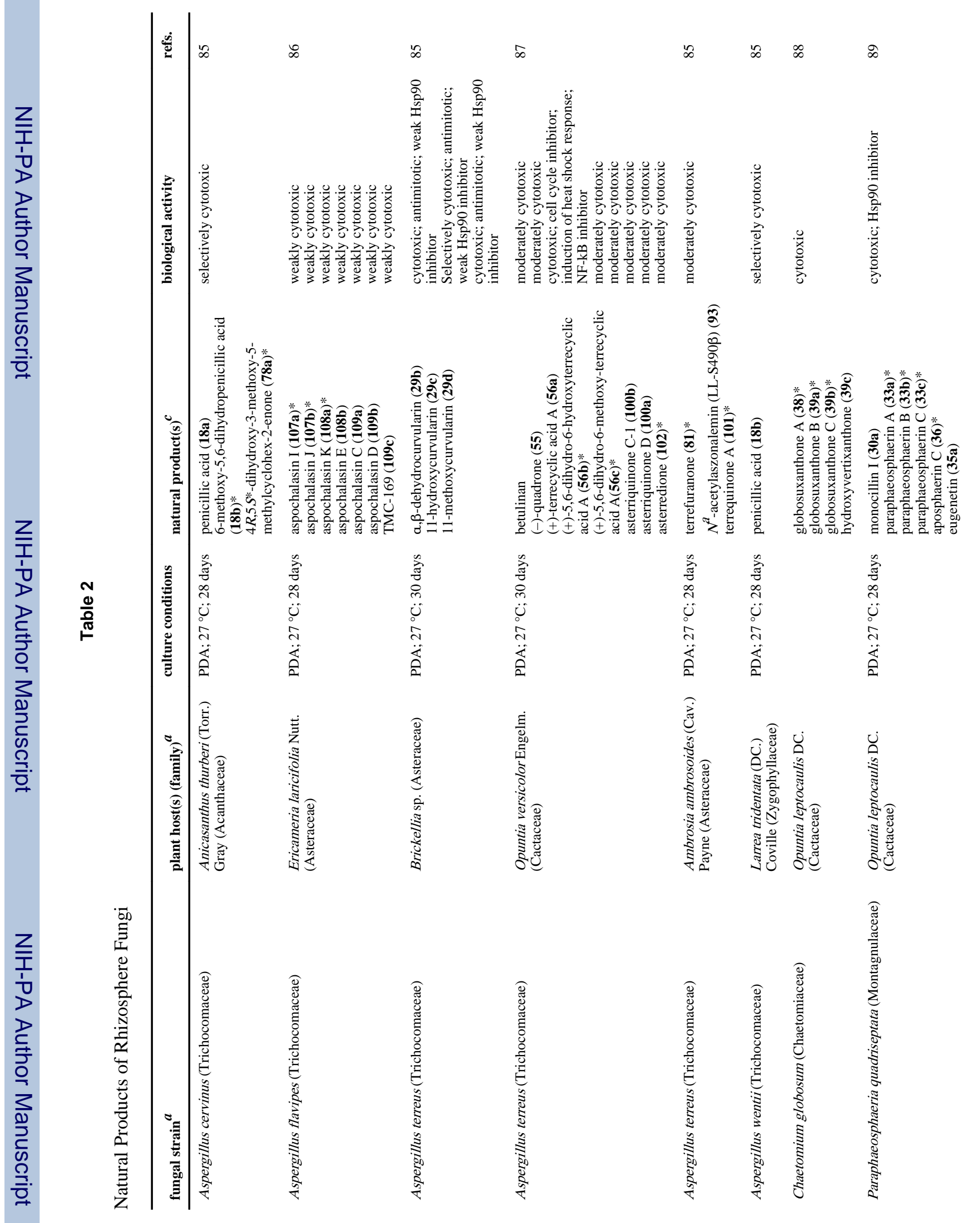




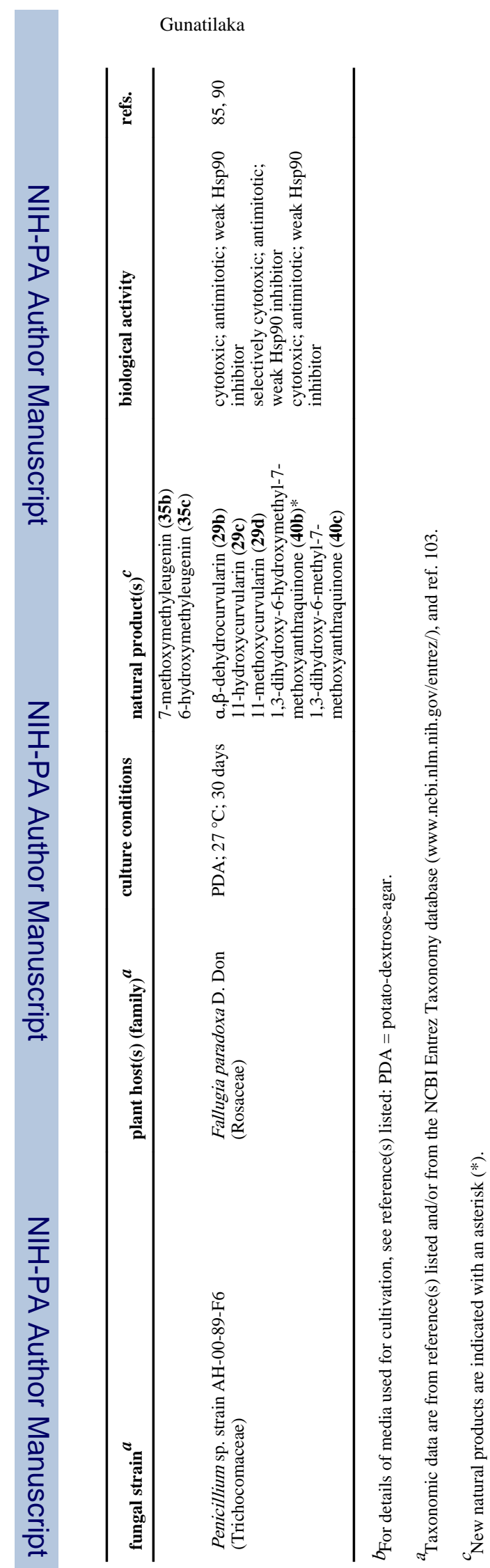

J Nat Prod. Author manuscript; available in PMC 2012 May 29. 